\title{
Another economic miracle? The German labor market and the Great Recession
}

\author{
Ulf Rinne $e^{1}$ and Klaus F Zimmermann ${ }^{1,2^{*}}$
}

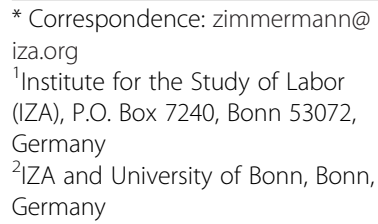

* Correspondence: zimmermann@ iza.org

${ }^{1}$ Institute for the Study of Labor (IZA), P.O. Box 7240, Bonn 53072, Germany

${ }^{2}$ IZA and University of Bonn, Bonn, Germany

\begin{abstract}
Germany's labor market responded only mildly to the Great Recession. Important factors for this development include the strong economic position due to recent labor market reforms, the crisis affecting mainly export-oriented companies, the extension of short-time work, time buffers due to working time accounts, the behavior of social partners, and automatic stabilizers. We emphasize the important interaction between short-time work and long-term shortages of skilled workers in sectors particularly affected by the crisis. Although Germany's experience is in stark contrast to the United States, we identify and discuss common challenges at the center of the future jobs debate.
\end{abstract}

Keywords: Economic crisis, Germany, Short-time work, Unemployment, Labor market institutions, Internal flexibility

JEL codes: J68, J21, P52, O57

\section{Introduction}

It is a broad consensus that Germany's post-war economic boom constitutes an "economic miracle" (Giersch et al., 1992; Lang, 1990). This perceived miracle refers to the period in which West Germany, badly destroyed after World War II, caught up with the development of the world economy. During the recent financial and economic crisis the country experienced what may be considered to be another economic miracle: the surprisingly mild response of the labor market to the worst global recession in post-war history.

What can explain the German success story? The underlying factors are related to the improved functioning of the country's labor market, the specific nature of the crisis in the German context, as well as the concrete policy responses in this critical period. A number of institutional factors have created an environment that is more difficult to generate or to replicate elsewhere.

From a long-term perspective, the German economy had made impressive progress to attack its classical Achilles' heel - the labor market - until 2008. Substantial labor market reforms making low-skilled labor productive helped put the economy into a relatively strong position when the crisis started. While the long-term unemployment rate could be substantially reduced, skilled labor in the best-managed and successful companies, typically in the export sector, became increasingly scarce. This is important to recognize in this context as the crisis in Germany mainly affected export-oriented companies, in particular manufacturing, and not the consumption sector. Firms affected by the Great Recession had a strong interest in retaining their qualified workforce against the background of population

(c) 2012 Rinne and Zimmermann; licensee Springer. This is an Open Access article distributed under the terms of the Creative Commons Attribution License (http://creativecommons.org/licenses/by/2.0), which permits unrestricted use, distribution, and reproduction in any medium, provided the original work is properly cited. 
ageing and the expected future shortages of skilled labor. Finally, the behaviors of social partners and automatic stabilizers have also helped cushion the labor market impact of the crisis. We argue that all these factors together have resulted in the country's recent success story. Firms affected by the Great Recession reacted mainly at the intensive margin to retain their workers. Next to the reduction of overtime hours and other instruments of working time flexibility if available at the firm level (e.g., working time accounts), short-time work was the instrument through which this could be managed at reasonable costs. Our explanation therefore emphasizes the central role of the interaction between short-time work, or more generally working time reductions, and increasing shortages of skilled workers in sectors and regions that were mainly affected by the crisis. This interaction is typically missing in other explanations of the German economic miracle (e.g., Burda and Hunt, 2011). Germany has proven to be a strong case of internal flexibility in response to the Great Recession.

The German success story is in stark contrast to the situation in the United States, which now has to worry about persistent long-term unemployment. More than 20 years ago the phenomenon of successive, recession-related waves of unemployment that ended up accumulating was considered to be entirely a European problem (Blanchard and Summers, 1986). Among the countries in Europe, Germany served as the prime example for the pattern of high and rising unemployment. The situation has remarkably changed since the 1990s when the impressive employment growth in the United States was frequently characterized as an "employment miracle" (Krueger and Pischke, 1997). We argue that this striking change is mainly due to successful labor market reforms in European countries such as in Germany and due to demographic changes. The Great Recession has merely acted as a shock that made the change apparent.

This paper proceeds as follows. We outline how the crisis had an impact on the country's economy, how policy responded, and how the German success story emerged. Finally, we conclude and discuss future challenges.

\section{Another economic miracle? The Great Recession in Germany}

It seems like that Germany has experienced another economic miracle recently, at least in the labor market. The country has been hit relatively hard by the crisis (Figures 1 and 2). Its GDP declined by 4.7 percent in 2009 compared to the previous year. This decline is larger than the output reduction in the United States, France, or the United Kingdom. Among the countries considered, only Japan did worse than Germany. While economic recovery took place early in Japan and in Germany, GDP in the United States declined even further.

But the German recession has, unlike in the other countries, never translated into an employment decline. Quite to the contrary, the size of the German working population remained at a record level of more than 40 million people through both 2008 and 2009 (Figure 3) and reached a new record level in May 2011, when the number of employed exceeded 41 million. Other countries experienced a substantial drop in employment levels. For instance, employment declined at peak by more than 2 percent in the United Kingdom and by about 6 percent in the United States.

When looking at unemployment rates, Germany's recent performance is also remarkable by international standards (Figure 4). Whereas the level of unemployment in 


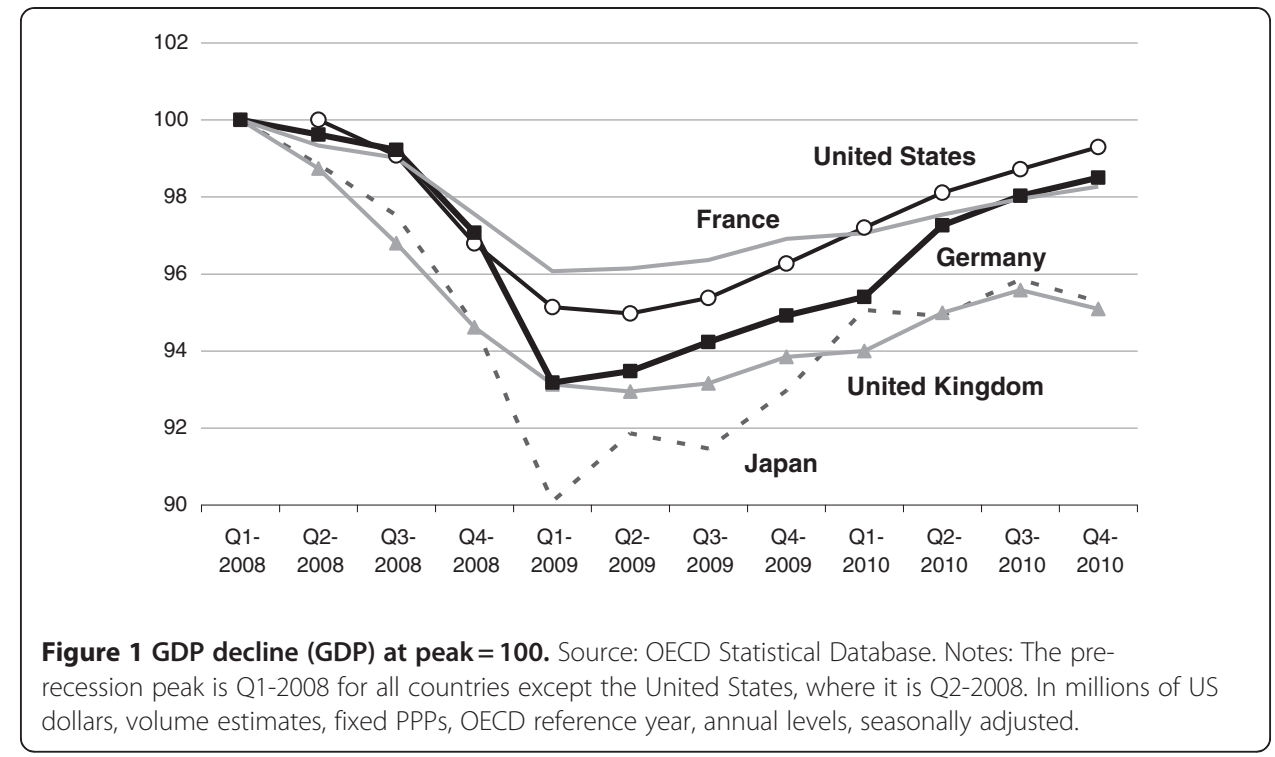

countries such as the United States, the United Kingdom or France increased substantially since early 2008, the increase was only moderate in Germany. By the end of 2010, unemployment in Germany was even lower than at the beginning of the recession. However, the picture changes for hours worked per worker (Figure 5). Except for France, average working hours declined in all major OECD countries. But this reduction was particularly strong in Germany. The reduction in working hours was the major source of adjustment in the German labor market in response to the shock. Although it is difficult to judge whether adjustments at the intensive margin are generally preferable over adjustments at the extensive margin, at least in the case of Germany during the Great Recession it appears as a successful strategy. Nevertheless, there are cases in which structural adjustments and labor reallocation are the better alternative to short-term stabilization of existing jobs - depending on the specific nature of the shock.

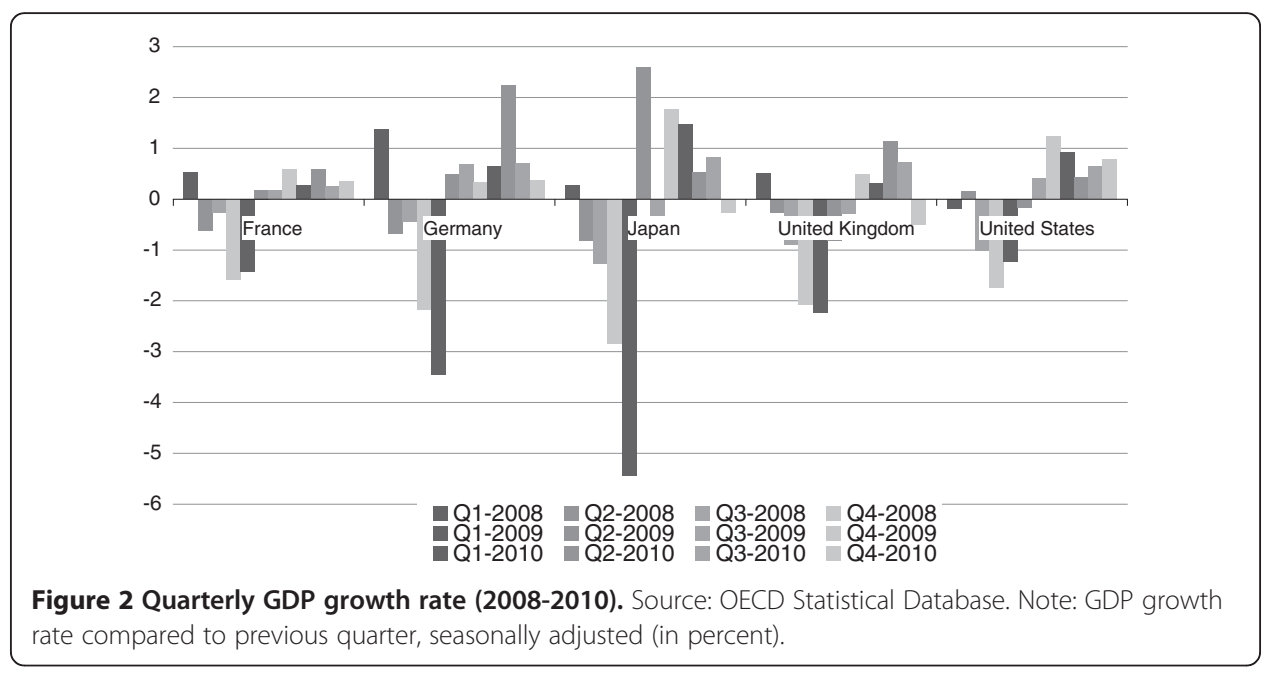




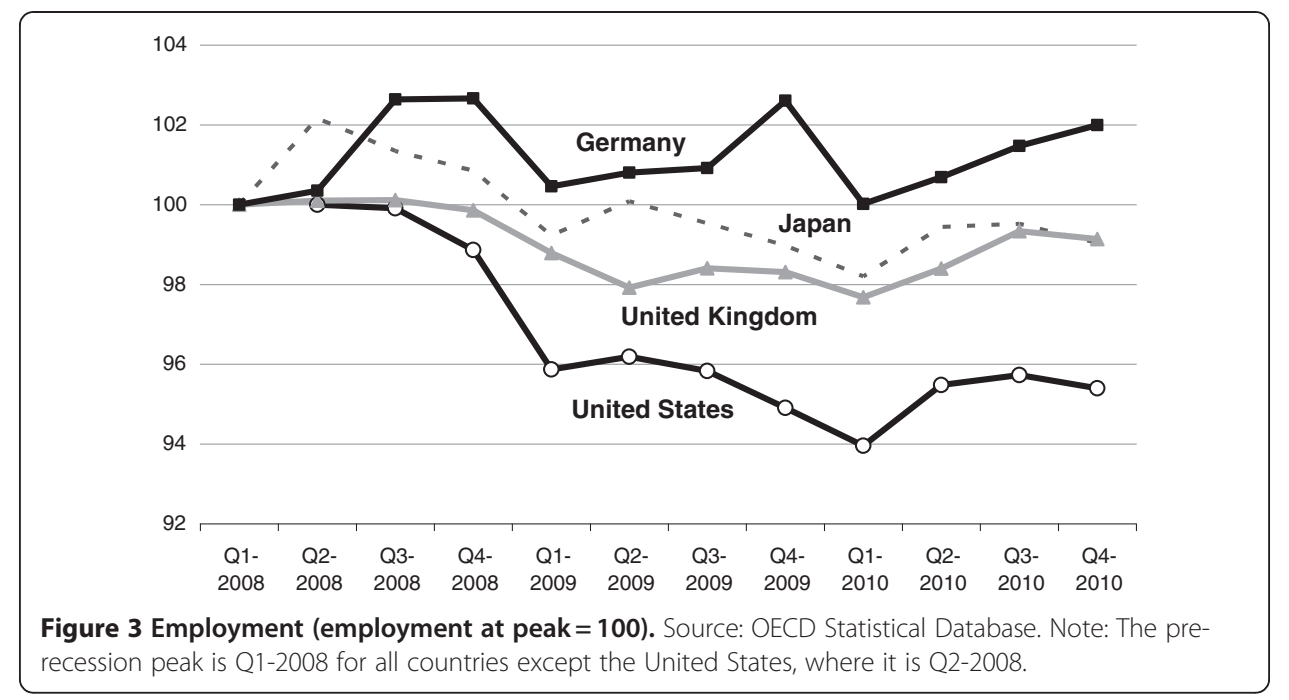

Hence, the German economic miracle can be described as one of a stable labor market in 2009 and beyond, where employment stayed high and unemployment moved up only marginally with lower working hours per person - in spite of a substantial output decline. Although the loss in GDP was much larger in Germany than in France, the United Kingdom, or the United States, the development of employment and unemployment was much more positive in Germany than in these countries. Japan has shown a somewhat similar experience: its output decline has even been more dramatic, but the labor market response was somewhat more negative than in Germany. However, Japan and Germany are very similar in the fact that both are strongly export-oriented countries and hours worked per worker were reduced substantially in both countries. In comparison with the United States, Germany has had a more substantial breakdown in output and has seen a much slower economic recovery, while the United States has faced a substantial rise in unemployment and a decline in employment.

The economic crisis had emerged in the United States and was subsequently imported to Germany. There are three channels through which this could have happened:

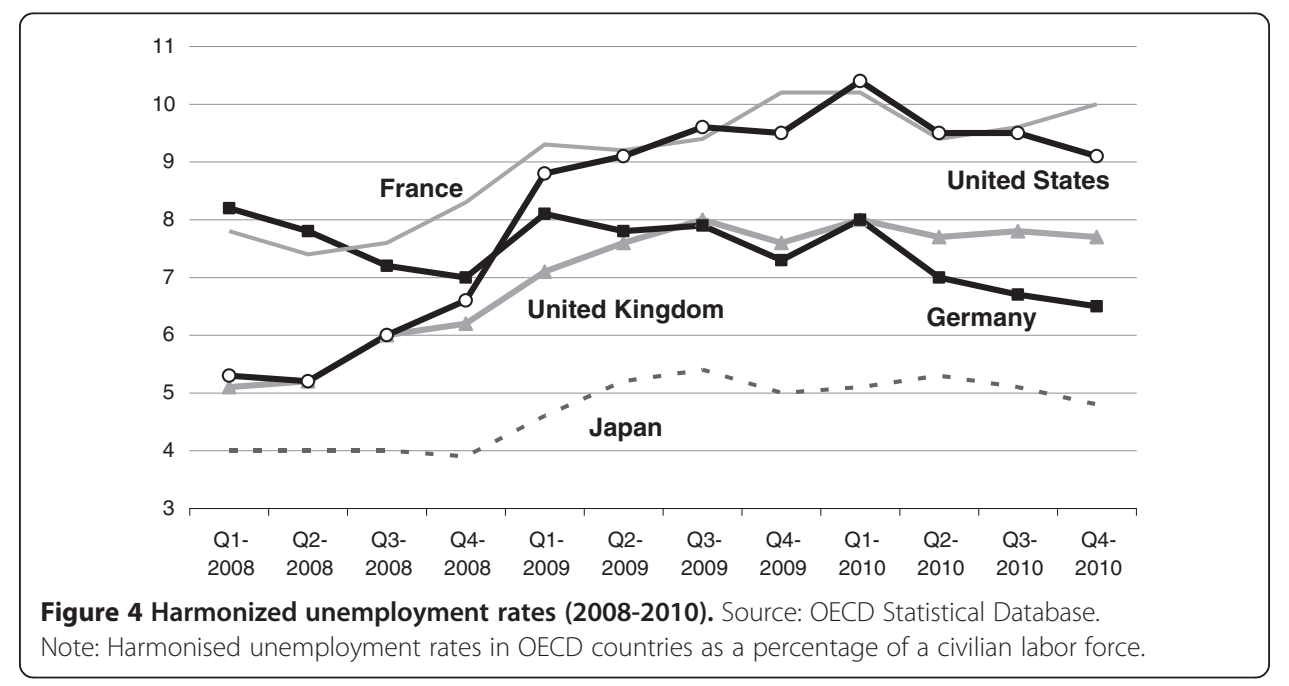




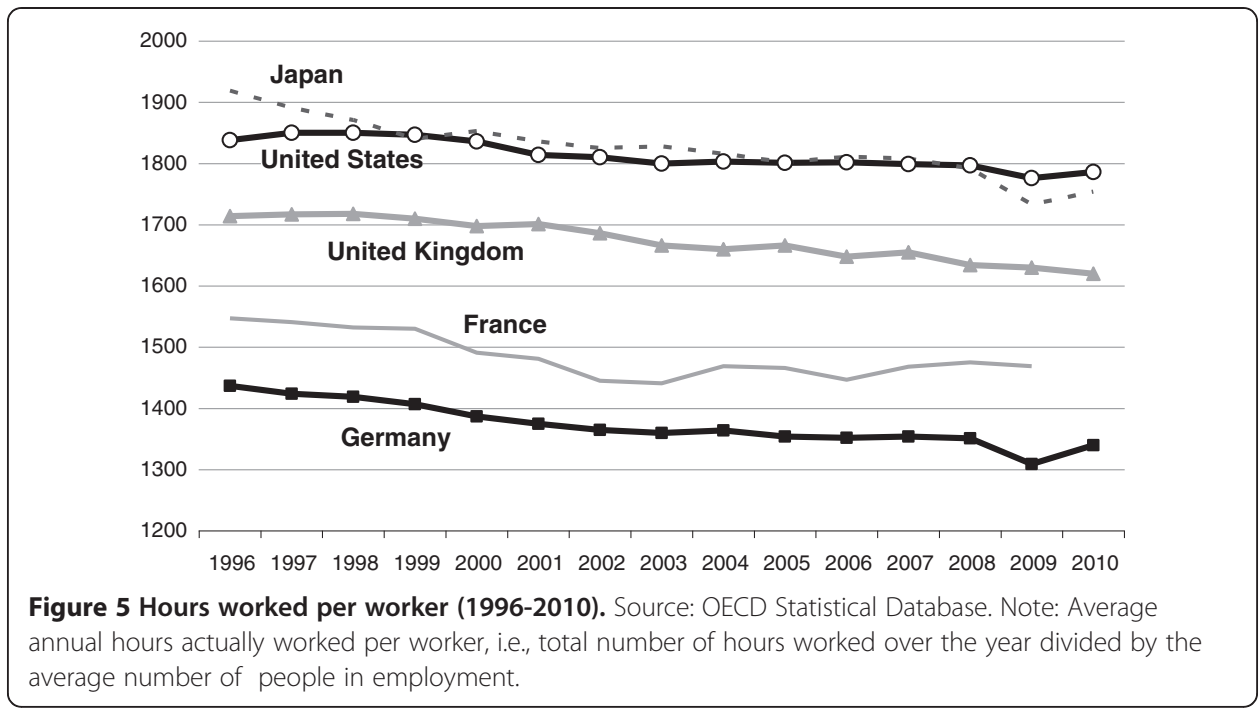

a) through the interdependencies of international stock markets and financial markets, b) through Germany's exports to the United States and to other countries affected by the crisis, and c) through deteriorating expectations of individuals, households, and firms. In fact, the recession's impact in Germany was almost exclusively based on declining exports, and it was located in the capital goods industry. This confirms Germany's strong dependence on the world market and the large interrelationship of its business cycle with the development of the world economy. Most recessions and booms in the country's history have resulted from this linkage. But the novel feature of this crisis was the simultaneous drop in demand for capital goods in German export markets around the world.

The German economy was hit by the crisis in late 2008 when GDP dramatically declined in the fourth quarter of that year. The decline continued in the beginning of 2009, but already in the course of 2009 the German economy started recovering - at least in some sectors. Nonetheless, GDP dropped by 4.7 percent in 2009 compared to 2008. This output decline was particularly strong in export-oriented sectors (e.g., manufacturing and related industries), whereas sectors related to private consumption were less affected (Figure 6). On the other hand, economic recovery in 2010 was particularly strong in those sectors that had previously experienced the largest output declines. Manufacturing is again the prime example with an annual GDP growth of 11.5 percent in 2010. The main shock affecting the German economy was therefore a transitory external demand shock. The particular nature of the shock with relatively stable private consumption has certainly helped cushioning the crisis' impact as the strategy of adjusting mainly at the intensive margin could be sustained.

The regional pattern of GDP growth reinforces the picture of heterogeneous impacts of the Great Recession in Germany. It is the economically important federal states such as Baden-Württemberg that reported the largest output declines (Figure 7). Many manufacturing firms and export-oriented small- and medium-sized firms are located in this state. In contrast, the GDP decline was relatively moderate in states such as Berlin, SchleswigHolstein, and Mecklenburg-Western Pomerania, which have low international exposure.

The same holds true when considering the annual changes in unemployment rates. The increase in the unemployment rate between 2008 and 2009 exceeded 5 percentage points in Baden-Württemberg, Bavaria, Hamburg, Rhineland-Palatinate and North 


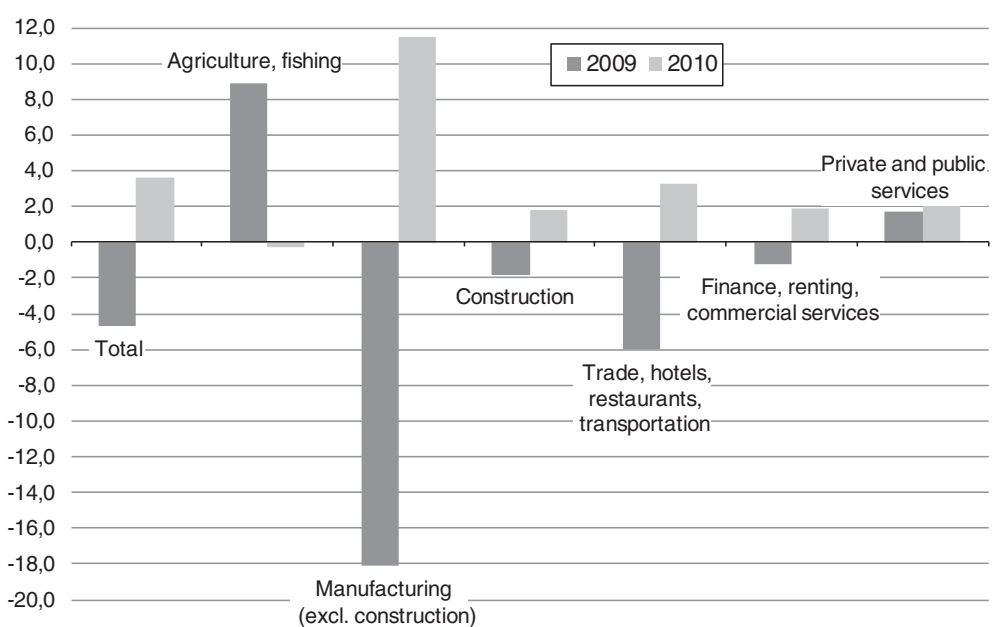

Figure 6 Annual GDP growth by sector (2009-2010). Source: Federal Statistical Office.

Rhine-Westphalia (Figure 8). These regions are located in West Germany, rely relatively strongly on exports, and are typically considered as economically prosperous German regions. The remaining federal states experienced lower increases, and most East German federal states did not experience increasing unemployment rates at all.

The current economic outlook for the German economy is rather positive, although the debt crisis in a number of countries, and more specifically imbalances in the fiscal policies of some member states of the European Monetary Union, threaten economic recovery. Yet the Great Recession ended in 2010 as GDP grew by 3.7 percent in Germany. The development of employment and unemployment also indicate more of a loosening rather than a tightening of the German labor market. For instance, employment (seasonally adjusted) has steadily increased throughout 2011 and 2012. It peaked at 41.5 million in May 2012, which is currently the latest available figure from the Federal Statistical Office.

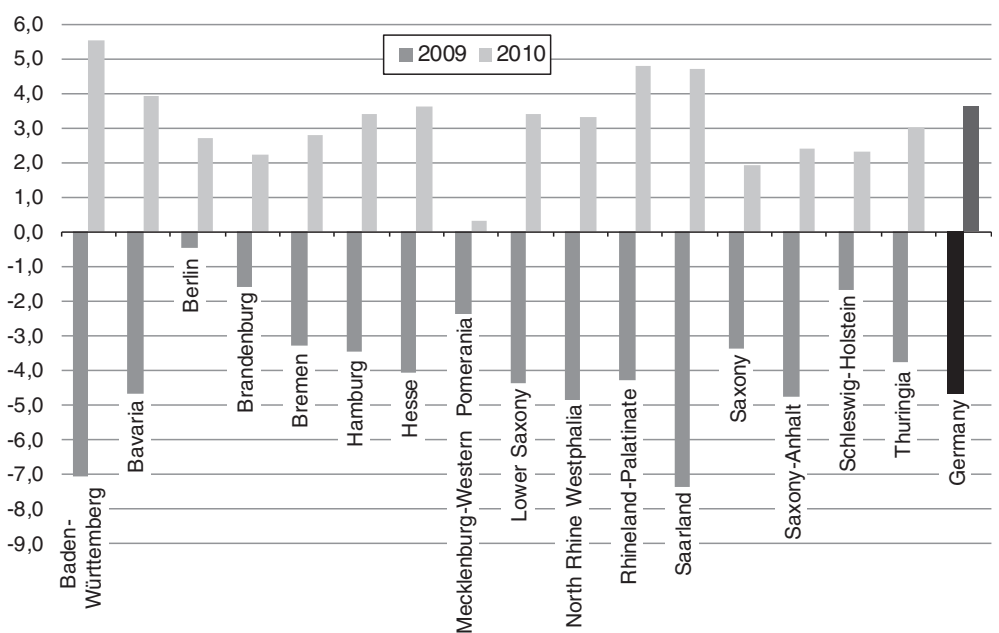

Figure 7 Annual GDP growth by federal states (2009-2010). Source: Federal Statistical Offices of the Federal States. 


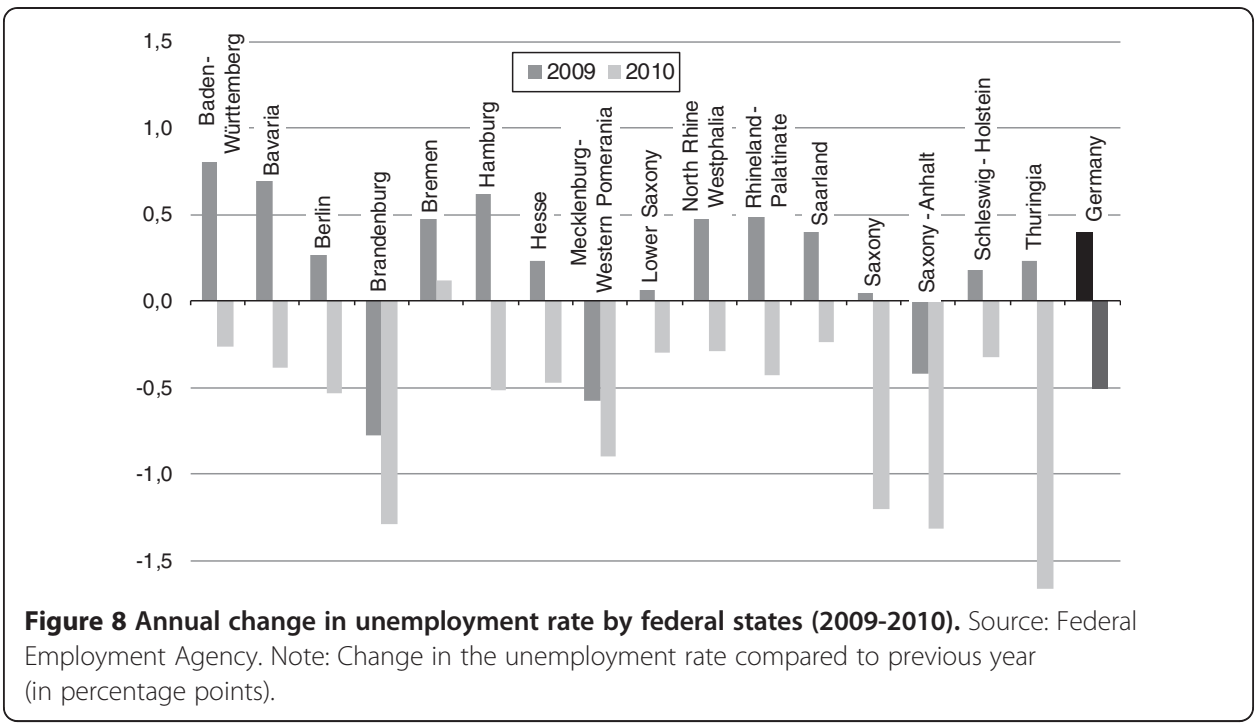

We discuss the perspectives (as well as a number of challenges) for Germany's future economic development in more detail in our conclusions.

\section{Post-reunified Germany: From Europe's "Sick Man" to the Agenda 2010}

Germany's recent success story is strongly linked to the country's reform efforts in the last decades. After the German reunification in 1990, the country faced serious problems in the labor market. Overcoming the high level of unemployment was crucial for the "sick man in Europe." These problems have often been linked to the high level of employment protection, high labor costs, and the strictly regulated labor market. During the 1990s, a number of policy measures addressed these problems, but the outcome was far from satisfactory. The adjustments merely addressed the symptoms, but the sickness was still there: at the turn of the century, the German unemployment rate was among the highest in Europe.

Although the availability of rather generous insurance-based social benefits related to labor market status and depending on previous wages (i.e., in the tradition of the "Bismarckian" welfare system; see, e.g., Hachon, 2010) helped limiting income inequality and wage dispersion, these results came at the cost of a strong segmentation of the labor market and a large stock of long-term unemployed (Eichhorst et al., 2008). The German welfare state was thus at risk of losing its sustainability; and the increasing burden of nonwage labor costs to cover deficits in social insurance seriously jeopardized Germany's international competitiveness.

Therefore, a series of labor market reforms was initiated in 2003 (Figure 9). ${ }^{1}$ Developed under the framework "Agenda 2010," the reforms successfully addressed the German labor supply problem, among other things by providing the right incentives for older workers to return to work. The reforms also abolished ineffective instruments (e.g., jobcreation schemes), reorganized long-term unemployment benefits, and introduced the requirement to prove job search effort. ${ }^{2}$ As a result, some impressive developments in the German labor market were observed. For instance, the labor force participation rate of 


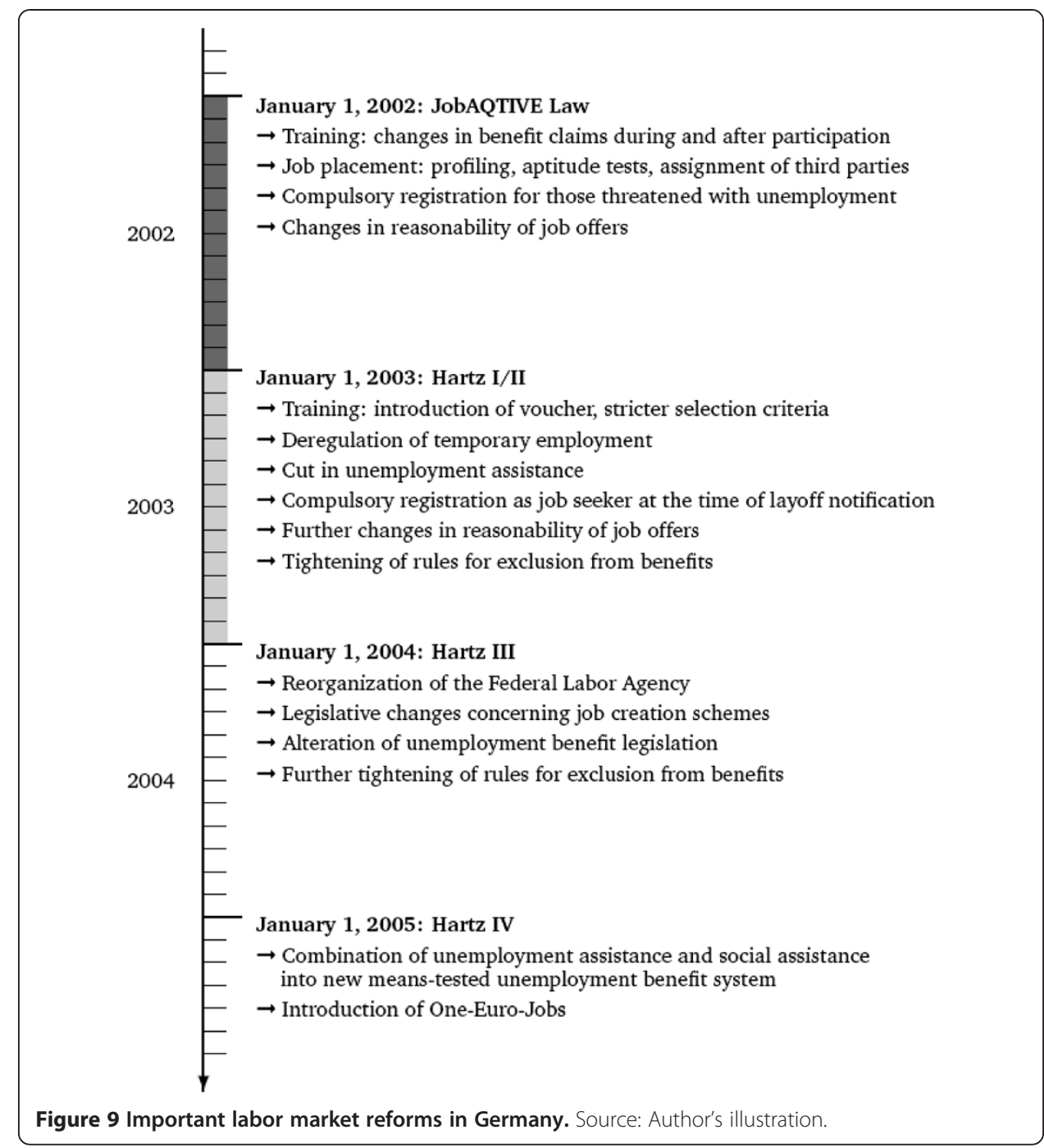

older workers, aged 55-64, rose by almost 20 percentage points since 2003, and was at 62.5 percent in 2010 (Figure 10). This is mainly because early retirement schemes were removed, and therefore many older workers decided to stay economically active. But also the labor force participation rate of the young, aged 15-24, rose by more than 5 percentage points between 2003 and 2008. Early interventions with monitoring and placement activities had their effects. For example, the acceptance wages of previously unemployed workers declined (Schneider, 2008). During the Great Recession, the youth labor force participation rate slightly declined by about 1 percentage point. ${ }^{3}$

All these efforts have translated into a remarkable achievement: for the first time in three decades, the base level of unemployment was reduced. This notable development becomes apparent when considering the total number of unemployed, with about 600,000 fewer unemployed people in the last boom in 2008 than at the lowest point in the previous boom in 2000. Additionally, the number of people receiving long-term unemployment support is now 20 percent lower than in early 2006 (Figure 11). Key to these improvements were stricter monitoring activities that raised the standards for collecting unemployment benefits and more effective placement and support services for job 


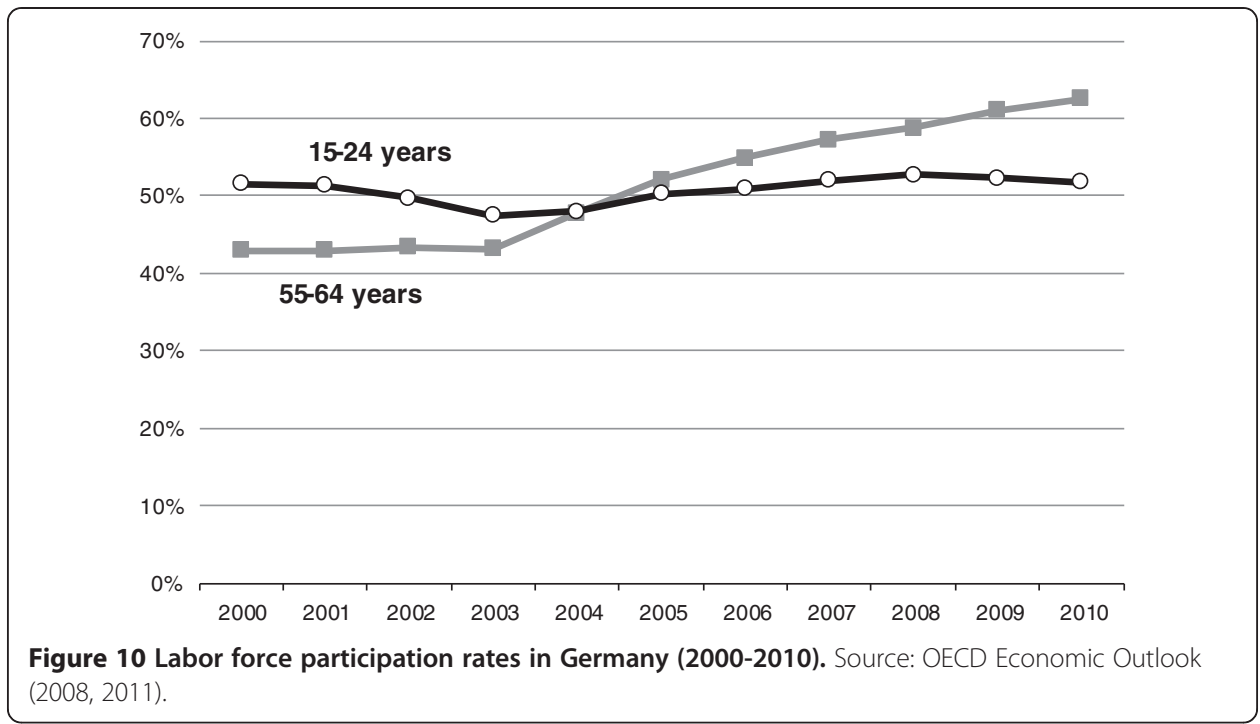

seekers that improved their labor market reintegration. The unemployed were much more willing to consider lower pay or a longer commute to work. That has helped to reduce the average unemployment duration, and to cut in half the number of people receiving unemployment benefits for up to a year after their layoff (Schneider, 2008).

Germany has thus been on the right track with its recent labor market reforms: the effectiveness and efficiency of labor market instruments has been increased, the incentives for unemployed individuals to take up jobs have been improved, and labor force participation rates have increased (Caliendo, 2009). These developments have contributed to putting the German labor market in a relatively strong position when the economic crisis hit the country. For instance, the country's international competitiveness was reestablished by then as the development of unit labor costs demonstrates (Figure 12). Germany kept its level stable, while unit labor costs were rising substantially in the United Kingdom, France, and the United States; they were declining strongly in Japan.

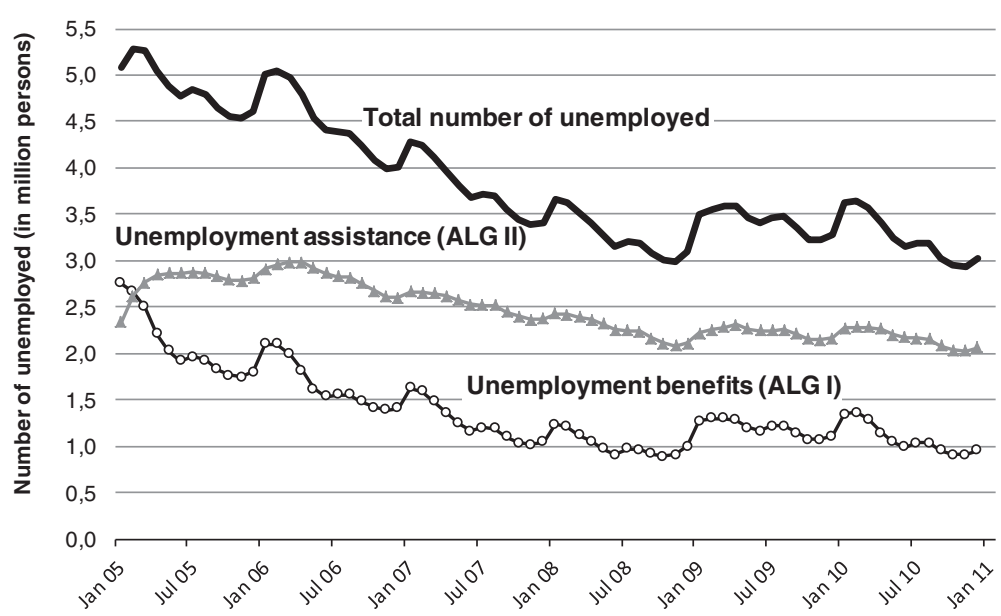

Figure 11 Number of unemployment by source of benefits (2005-2010). Source: Federal Employment Agency. 


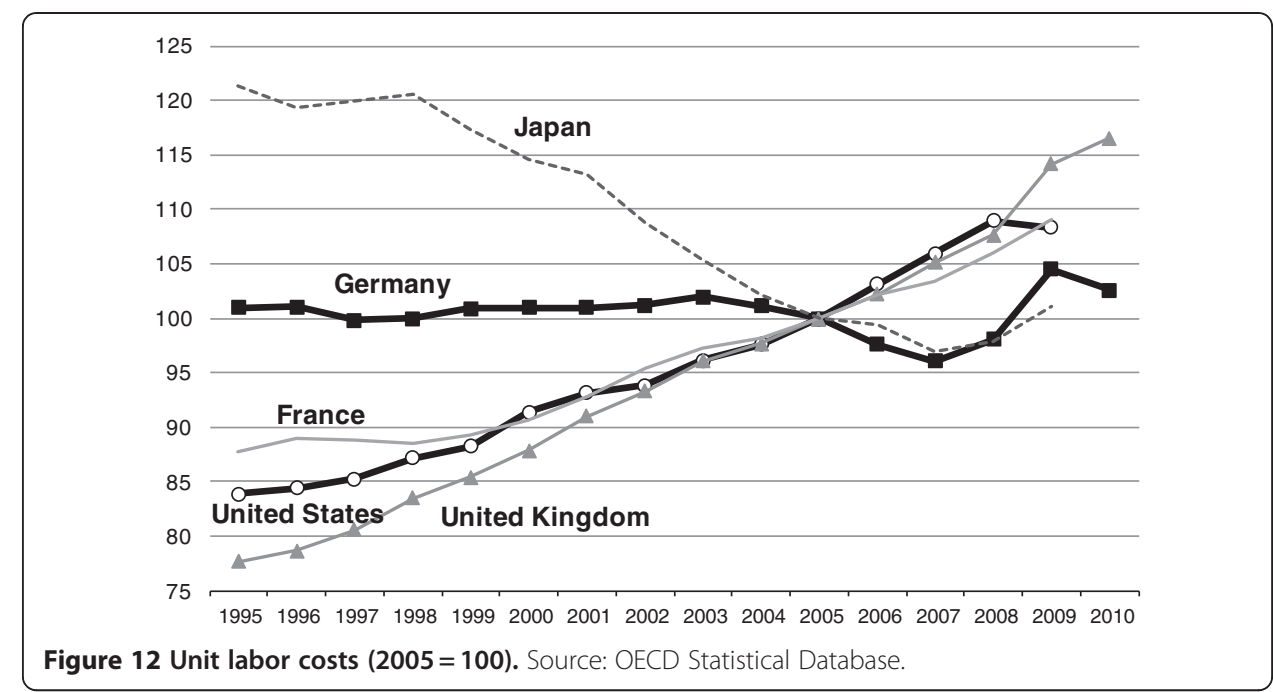

The decline in unit labor costs in Germany is related, among other things, to the behavior of social partners. Trade unions have shown a comparatively large degree of wage restraint in recent years, and collective bargaining processes have generally resulted in moderate wage growth. Moderate wage growth was accompanied by adjustment, restructuring, and reorganization processes within firms. Labor income has thus been lagging behind capital income for many years; and firms were relatively competitive by the end of 2008 .

Importantly, the German labor market has become more flexible in recent years, especially at the margin. Whereas the traditional institutional setting of standard employment has been preserved, it has been accompanied by a growing segment of nonstandard forms of employment such as marginal employment and temporary agency work (Eichhorst and Marx, 2011). The development of the German labor force in recent years is characterized by a decreasing share of permanent full-time employees, by an increasing percentage of employees in flexible jobs, and by a decreasing share of inactive individuals. For example, while the share of permanent full-time employees has declined from 45 percent in 1992 to 38 percent in 2007, the fraction of inactive persons has declined from 25 percent to 21 percent within the same period of time (Eichhorst and Marx, 2011). The share of standard forms of employment, moreover, differs widely across sectors. It is much higher in sectors such as manufacturing or construction than in public, personal, or business services.

Altogether, the German economy had made impressive progress on its classical Achilles' heel - the labor market - until late 2008. This was the time when the worst global recession in post-war history emerged also in Germany.

\section{Discrete policy responses: Stimulus packages, "cash for clunkers," and short-time work}

Standard economic textbooks describe the recipe against the financial crisis which emerged in late 2008 as follows: internationally coordinated flooding of money, low interest rates, a guarantee on inter-bank loans and saving accounts, restructuring of management, fresh public equity capital via a temporary nationalization of banks, 
relieving ailing banks from toxic assets by transferring these assets into publicly sponsored work-out units (so-called "bad banks"), and establishing a new international financial regime. Such reactions happened, but rather slowly and only gradually. In particular, there was no internationally coordinated comprehensive approach, especially not with respect to toxic assets and the reorganization of the financial regime. ${ }^{4}$

However, there were various discrete policy reactions on the national level. Besides new regulations of the capital and financial markets, stimulus packages were extremely popular. Germany was no exception to this rule. Against the background of the imminent recession, the German government introduced two stimulus packages in late 2008. The expenditures of these packages amounted to about $€ 36$ billion in 2009, or 1.5 percent of the country's GDP in that year, and almost $€ 47$ billion or 1.9 percent of GDP in 2010 (Leifels et al., 2009). The total volume of both stimulus packages was $€ 82$ billion, i.e., almost exactly $€ 1,000$ per capita. The first package included, e.g., a personal income tax deductibility of health care contributions, an increased child benefit and child tax deduction, and a reduction in unemployment insurance contributions. The major budget items of the second stimulus package were investments in transport infrastructure, income tax deductibility of handymen services, and a more attractive depreciation of investments in immovable property. ${ }^{5}$ The fiscal stimulus induced by these measures appears to have been modest, especially in 2009.

There were, however, two measures that received a lot of attention in the public debate and also had an immediate impact on the economy: a) the controversial "cash for clunkers" program, and b) the extension of short-time work.

As part of its second stimulus package, the German government introduced a program similar to the "cash for clunkers" program in the United States. Car holders willing to buy a new car in exchange for their at least 9-year-old car would receive a subsidy of $€ 2,500$. $^{6}$ Total expenditures of this program were limited to $€ 1.5$ billion when the program was announced, but subsequently the limit was extended to $€ 5$ billion. In total, 2 million cars have been bought under this program, which corresponds to the limit of the subsidy. This limit was reached in September 2009 when the program was stopped. The program had an immediate impact on the economy; it was very visible and was widely discussed. Although the subsidy helped stabilizing private consumption to some extent, its windfall gain is estimated to be substantial. Roughly 75 percent of the cars would have been bought also without the program and, hence, net fiscal costs were about $€ 2.6$ billion (Blum and Freye, 2009). Moreover, the program focused on one particular industry, namely the car industry and its suppliers. This sector of the economy had already suffered from overcapacities for many years. Structural adjustments were needed, but these have been very likely postponed due to the program.

The extension of short-time work may be labeled as the "German answer" to the economic crisis (Brenke et al., 2011). This traditional instrument - its roots can be found around the turn of the twentieth century in the tobacco industry - has been rediscovered during the crisis. Short-time work was extensively used after the German reunification to accompany structural change when primarily East German workers were affected (Figure 13). A recession in West Germany in the early 1990s led to another substantial increase in the stock of short-time workers, but subsequently the number was relatively low - until late 2008. During the crisis, the number of short-time workers strongly increased and peaked at more than 1.5 million in May 2009. During the 


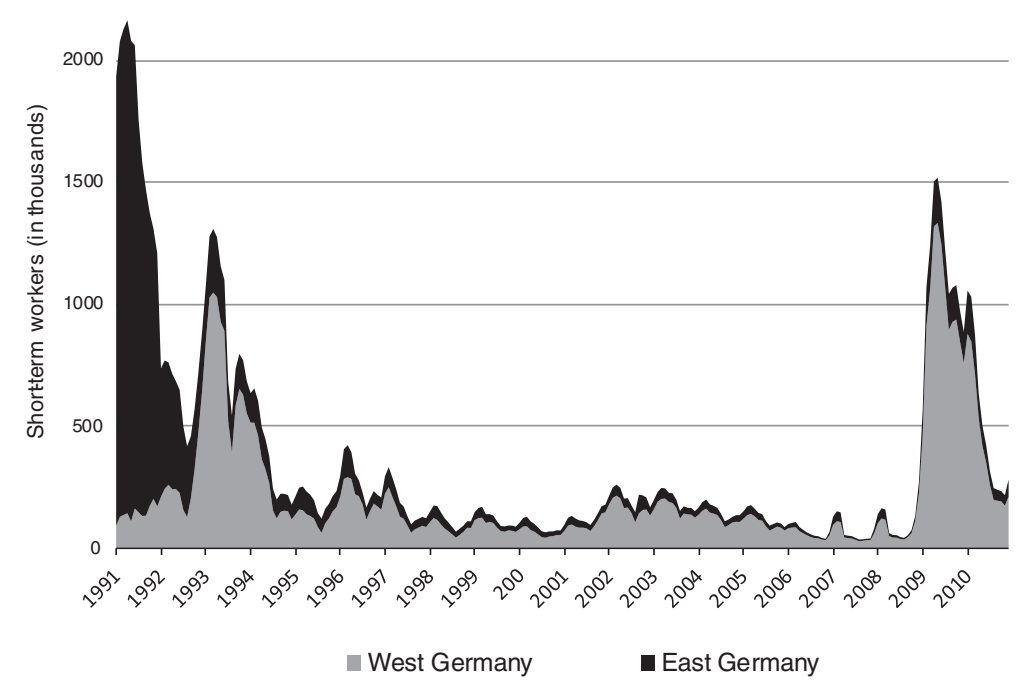

Figure 13 Stock of short-time workers (1991-2010). Source: Federal Employment Agency.

second half of 2010 the number of short-time workers stabilized below 300,000 individuals. Brenke et al. (2011) conclude that without the extensive use of short-time work, unemployment would have risen by about twice as much as it actually did in 2009 .

Short-time work was especially common in Germany's industrial sectors that rely heavily on exports as well as those service sectors closely linked to industrial production. At the end of 2009 one in six of those with jobs subject to social security contributions and employed in machine construction and metal production worked reduced hours; in the automobile industry it was one in seven (Brenke et al., 2011). However, short-time workers were also found in sectors such as the service industry or public administration in which no discernible reasons for the reduction in work hours were present. These sectors should not have been affected, either directly or indirectly, by weak foreign demand. It therefore seems to be the case that these sectors have resorted to short-time work not because of economic circumstances, but more because of internal difficulties or structural problems. Although the majority of firms with shorttime work are small companies, it is large firms in particular that have been affected with regards to the number of employees.

The extensive use of short-time work is certainly related to amendments to laws and regulations that were introduced in light of the Great Recession. Short-time work would have certainly also been used without these amendments during the crisis, but, for example, the sequential increase in the maximum period during which this subsidy could be paid and lower costs to employers made this instrument much more attractive to use. ${ }^{7}$ It is nevertheless still the case that whereas the loss of income an employee incurs through short-time work is kept to a minimum, firms are faced with particular disadvantages - and costs. ${ }^{8}$ For instance, labor costs incurred with short-time work do not fall proportionately with the reduction in working hours because of residual costs (e.g., costs remain for paid leave and other agreed payments). However, firms were willing to incur these costs, mainly to preserve employees in the established core of the company and to remove the necessity of having to employ new personnel once demand improves. In this manner, they are spared the costs of finding and training new personnel, which 
can be considerable. Employers also avoided severance payments and potential claims against unfair dismissal. These considerations are especially relevant in Germany as the country faces long-term shortages of skilled workers in sectors and regions that were particularly affected by the crisis. This outlook certainly created additional incentives for firms to incur the costs that are associated with the use of short-time work.

\section{Automatic stabilizers: Working time accounts, and the tax and transfer system}

Next to discrete interventions, automatic stabilizers may have played an important role during the Great Recession. In this context, working time accounts as well as the tax and transfer system appear relevant to provide the full picture of the German success story.

Working time accounts act as (quasi-)automatic stabilizers. If employees work fewer hours than their contractual obligation, working time accounts ensure that this debt will be balanced later. In these cases, firms give a credit to their employees (the full salary), and they receive compensation once demand improves (in the form of labor). Working time accounts thus help companies to smooth employment levels and adjust working hours over the business cycle. Hence, they may have been an alternative to the use of short-time work in the adjustment process at the intensive margin. Indeed, about one third of the companies in Germany with more than 20 employees used working time accounts to maintain employment levels during the crisis (Zapf and Brehmer, 2010). In 2009, the reduction in working hours that was due to working time accounts was about half of the size of the reduction that was due to short-time work (7.0 hours vs. 13.4 hours per employee; Zapf and Brehmer, 2010). ${ }^{9}$ Taking into account deadweight losses that might be associated with the use of both measures, the number of jobs that were saved is about 320,000 for working time accounts and roughly 400,000 for short-time work (Boeri and Brücker, 2011). A majority of firms that used short-time work also used working time accounts (51.8 percent), whereas fewer than one in ten firms that used working time accounts also made use of short-time work (Boeri and Brücker, 2011). Therefore, companies seem to have used working time accounts first to adjust at the intensive margin, and when individual accounts were close to zero, they switched their strategy and used the instrument of short-time work. This sequential approach is rational when considering the regulations governing the use of short-time work, and also when taking into account financial considerations. ${ }^{10}$ Although firms face particular costs when they use short-time work as demonstrated above, these costs are lower than the costs that firms incur when they use working time accounts. In the latter case, no compensation is paid by the Federal Employment Agency and firms have to pay the full salary. Therefore, only firms in a sufficiently good financial situation could sustain the use of working time accounts during the crisis. ${ }^{11}$

The tax and transfer system also acts as automatic stabilizer. Importantly, the extent to which this is the case may differ across countries. Simulations of income and unemployment shocks show that the degree to which shocks are absorbed by the tax and transfer system is generally higher in the European Union than in the United States (Dolls et al., 2012). The difference is larger in case of an unemployment shock, which can be explained by the importance of unemployment benefits. Germany exhibits relatively high income stabilization coefficients, both for income shocks and unemployment shocks. These coefficients are larger than those calculated for France, the United Kingdom, and the United 
States (Dolls et al., 2012). It can thus be expected that the German tax and transfer system helped in stabilizing output and employment to a larger extent than in other economies. ${ }^{12}$

Finally, there is no evidence that countries with weak automatic stabilizers have enacted larger fiscal stimulus packages, or larger discretionary spending on active labor market policy measures (Figure 14). Whereas for instance Japan and the United Kingdom have increased their expenditures on these measures by comparatively large amounts, Germany and the United States both exhibited relative low expenditure increases. However, all major OECD countries increased expenditures during the crisis when compared to prerecession values. Japan is the country with the largest increase in this regard, as prerecession expenditure was almost doubled. Germany's discretionary reaction was very modest in this dimension as expenditure only increased by 2 percent.

\section{Explaining the economic miracle: Internal flexibility and labor hoarding}

What are the factors that can explain the surprisingly mild response of the German labor market to the worst global recession in post-war history? In general, we observe a large degree of working time flexibility. This means that in response to the economic crisis, employees worked less overtime and working time accounts have been substantially reduced. This certainly relies on the behavior of social partners, whose interest has mainly been the stabilization of existing jobs and employment.

The German government has additionally introduced complementary policies; among these, short-time work has turned out to be by far the most important instrument. Starting in late 2008, we observe a massive expansion of workers receiving government-sponsored subsidies for reduced working hours. Unemployment would have risen by about twice as much as it actually did in 2009 without this increase (Brenke et al., 2011). Firms retained their qualified workforce despite the Great Recession and followed a strategy of labor hoarding. Although working time accounts also played a role in this context, it appears doubtful that firms would

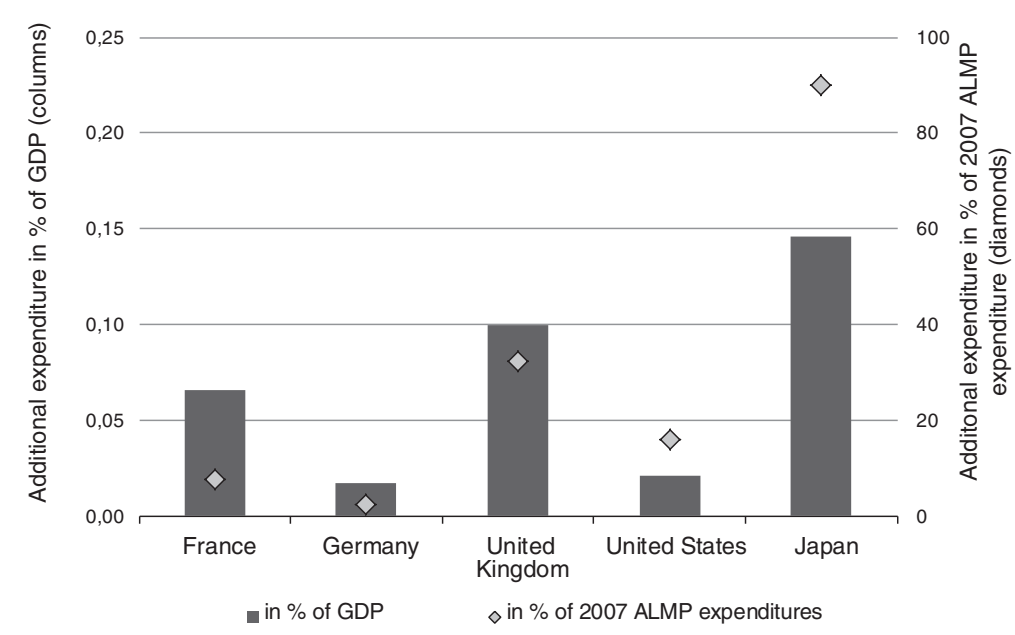

Figure 14 Discretionary spending on active labor market programs. Source: OECD Employment Outlook 2009. Note: Average annual planned additional expenditure for 2008-2010. 
have adhered to the strategy of labor hoarding without short-time work, given the severity of the economic crisis. ${ }^{13}$

Although empirical evidence shows that manufacturing firms, for example, often engage in labor hoarding in economic downturns (OECD, 2009), these considerations are of particular relevance in the German labor market with high employment protection legislation, and they are especially relevant in those sectors that were severely affected by the crisis. At the sector level, there is a clear positive relationship between the share of firms that were strongly affected by the crisis and the share of firms reporting recruitment problems in 2008 (Möller, 2010). The manufacturing sector serves as a prime example: output decline was particularly strong and there have been shortages of skilled labor for quite some time. ${ }^{14}$ Firms in this sector therefore had a great interest in retaining their qualified workforce despite the crisis. Short-time work was the instrument with which this could be managed at reasonable costs. And indeed, whilst before the economic crisis short-time work has been primarily used in the construction sector, the main emphasis shifted to the manufacturing sector during the crisis. In the middle of 2009 this sector accounted for four fifths of short-time workers (Brenke et al., 2011).

As a result of labor hoarding, we observe declining labor productivity in Germany between 2008 and 2009 (Figure 15). We observe a similar decline in the United Kingdom and to some extent in France, but for example not in the United States where labor productivity in fact continued to increase.

Despite efforts to stabilize employment through short-time work, or more generally through reduced working hours, there have also been job losses in the German labor market. These were concentrated in particular sectors, and in the more flexible segments of these sectors. For example, whereas employment in the manufacturing industries declined by roughly 4 percent during 2008 and 2009, employment in temporary agency work in this sector decreased by about 20 percent in the same period. ${ }^{15}$ The observed pattern of low-skilled and nonstandard workers facing above-average risks of earnings losses - in particular in manufacturing - is in line with the labor demand estimations by Bargain et al. (2012). For this group, automatic stabilizers in the tax and

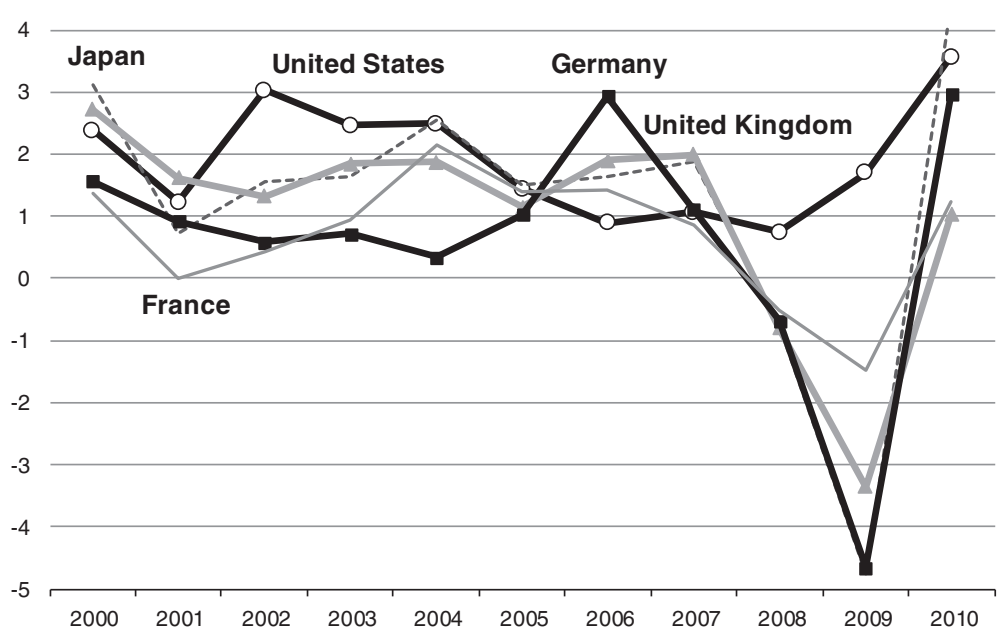

Figure 15 Labor productivity growth (2000-2010). Source: OECD Employment Outlook 2011. Note: Labor productivity measured as GDP per person employed. Percentage changed from previous period. 
transfer system are therefore relatively more important as a significant share in gross income losses could be cushioned (Bargain et al., 2012; Dolls et al., 2012).

Overall, Germany can be regarded as a strong case of internal flexibility. The labor market response to the economic crisis has mainly been a reduction in working hours per employee, and not a reduction in the number of employees. This reaction was moreover concentrated in the export-oriented sectors of the German economy, and in the more flexible segments of these sectors. We identify several factors that have contributed to this development, and other factors that were less important. Among the latter are the two stimulus packages which did not start before mid-2009, and the controversial "cash for clunkers" program whose scope was limited. The high employment legislation protection in Germany itself cannot explain the economic miracle, but it is nonetheless important to consider the interaction between the economic crisis and the institutional framework (Möller, 2010). In this context, we attach great importance to the interaction between short-time work and long-term shortages of skilled workers in sectors and regions that were mainly affected by the crisis.

\section{Conclusions and outlook}

Is the German model transferable to other developed countries? Some aspects of this model are certainly transferable, whereas other features are not. The long-term structural adjustments in the German labor market can definitely serve as a role model for other countries. A substantial part of the country's success story during the Great Recession is its recent reform efforts that have helped putting Europe's "sick man" back on track. The strategy of labor hoarding and internal flexibility could only be sustained because both the labor market and individual companies were in a relative strong position when the demand shock hit the country. In addition, the firms that were mainly affected by the crisis had the incentives and the necessary instruments to follow this strategy. Next to working time accounts, the discretionary extension of short-time work was particularly important in this context. On the other hand, some aspects of the German model cannot be easily replicated elsewhere. With regards to short-time work and its apparent success, it presumably helped that firms already had experience with using it. In addition, the crisis appeared in Germany as a sector-specific and transitory external demand shock. This specific feature is undoubtedly not transferable.

However, Germany is not the only country that has gone through the crisis without a significant rise in unemployment. For example, the Netherlands had a similar experience. And indeed, there are factors that make both cases comparable. First, the Netherlands experienced a transitory shock in external demand. The nature of the main shock was therefore similar to that in Germany. Second, the Netherlands also faces long-term shortages of skilled workers, which created incentives for firms to retain their qualified workforce during the crisis. Moreover, it is also the case that Dutch firms were in a financially good position when the crisis hit the country, and the government created a new short-time work scheme during the crisis (Cahuc and Carcillo, 2011). These factors appear important to adopt and to sustain a strategy of labor hoarding during the Great Recession. The crisis also had a relatively modest impact on the Austrian labor market. Similar to Germany and the Netherlands, the crisis hit the country as a transitory external demand shock, and a short-time work scheme existed during the crisis. 
Additionally, Austria is expected to face long-term shortages of skilled workers (Walterskirchen, 2001).

This brief comparison of selected countries suggests that the combination of (at least) three features seems to be related to successfully navigating the crisis: Germany, the Netherlands and Austria experienced a transitory shock in external demand; the three countries are expected to face long-term shortages of skilled workers; and the three countries had short-time work schemes available during the crisis. While the former two features create incentives to follow a strategy of labor hoarding, short-time work is a relatively attractive instrument to sustain such a strategy. ${ }^{16}$

One general conclusion that can be drawn from cross-country comparisons of labor market responses to the economic crisis is that countries with existing policy measures to quickly adjust fare relatively well. In those countries, no imminent need for discretionary measures or extensive reforms emerges. Instead, they can rely on automatic stabilizers that are already in place, for example in the tax and transfer system. Another general lesson is that previous reform efforts pay off, also and maybe in particular during a crisis. The implementation of activation policies has certainly contributed to the relatively comfortable position when the crisis hit Germany. Therefore, "flexicurity" can still be regarded as the (European) role model for institutional reforms. Despite fundamental changes in the economic environment, the model of balancing flexibility in the labor market with generous social protection and active labor market policies does pay off.

The policy responses to the Great Recession in various countries have shown remarkably few innovations. However, some countries adapted apparently successful policy measures from other countries and there have been relatively strong adjustments of existing policy measures. The extension of short-time work in Germany serves as a prime example of the latter. Furthermore, a return of passive measures (e.g., early retirement schemes) cannot be observed so far, and there is also no evidence for downsizing the role of ALMP or automatic stabilizers.

When reconsidering the German success story, the question remains whether the country will have to pay its bill later. At a certain point, structural adjustments and labor reallocation are in general the better (and inevitable) alternative to short-term stabilization of existing jobs. In other words, countries that fared relatively well so far in terms of the unemployment impact of the crisis are not necessarily the countries that will fare best in the medium and long run. It is true that internal flexibility in highly regulated labor markets can serve as an adequate short-term measure to keep unemployment low, and to sustain employment of qualified workers. But one has to keep in mind that this comes at the cost of delaying necessary and unavoidable structural adjustments and labor reallocation. Germany, however, still fares very well by international comparison. Employment rates have reached a new record high, unemployment has declined, and the number of short-time workers is low again. For this development it certainly helped that the export-oriented sectors, which were the most affected by the crisis in Germany, have recovered fast. The strategy of internal flexibility and labor hoarding has been mainly followed by firms in these sectors, and - thanks to the quick recovery - it turned out to be a successful strategy.

But in the aftermath of the economic crisis, structural change will certainly speed up at least in the longer run. And from today's perspective, it appears doubtful whether 
Germany is well prepared for this scenario. There are still a number of issues German policymakers should put on their future agenda. In social terms, three challenges stand out: the first is combating long-term unemployment; the second is creating gainful employment opportunities for low-skilled workers; and the third is to educate and attract skilled labor from abroad. Their talent is not only needed to modernize the economy, but also to provide employment opportunities for low-skilled labor.

These three challenges will be at the center of debate not only in Germany, but on both sides of the Atlantic. Regarding low-skilled labor, the country's basic problem is not that there is not enough work to be done. It is well known that Germany has an underdeveloped service sector, parts of which are hidden in a shadow economy that is estimated to account for up to one-sixth of GDP (Schneider, 2003). The key challenge is how to create incentives to engage in regular work. A powerful solution would be to impose the workfare principle on those receiving public benefits - i.e., no financial support without work or engagement in further education (Schneider and Zimmermann, 2010). This measure would make it costly not to take up a regular job. That may sound harsh, but even Scandinavian welfare states have taken similar steps.

Although the German apprenticeship system has proved to be successful in the past, some adjustments are needed. It is important to ensure that it includes, rather than excludes, young people with low qualifications. For example, shortening apprenticeship programs to two years and de-emphasizing theoretical knowledge would especially help young workers from immigrant families to get on track to gainful employment. The differences between immigrants and natives in terms of economic outcomes, including education, are still relatively persistent over migrant generations in Germany (Algan et al., 2010).

The ageing of Germany's population, the declining size of the workforce, and increasing shortages of skilled labor pose huge additional challenges. Given the already high level of social security contributions, there is no scope to place an additional burden on that shrinking labor pool. These people would lose the incentive to work. Germany needs high-skilled immigrants to cope with demographic change and a migration policy that is in line with Germany's economic interests (Schneider and Zimmermann, 2010). However, the country should be prepared to enter a global tug-of-war for talent (Constant et al., 2011).

There is the need for further adjustments in the future. But the lesson from the past several years of Germany's labor market reforms is clear enough: they worked - and they have helped to create another German economic success story, if not yet another economic miracle. Importantly, the need for institutional adjustments in Germany has not changed with the Great Recession. Given the country's impressive performance, current internal policy debates center around the question how to withdraw parts of the recent reforms. Current discussions, for example, challenge the gradually increasing retirement age and call for statutory minimum wages. These discussions are dangerous. To the contrary, there are a number of crucial challenges that need to be addressed through reforms - without putting past achievements at risk.

\section{Endnotes}

${ }^{1}$ Although the Hartz reforms only started in 2003, one may also include the JobAQTIVE law that came into force on January 1, 2002 in this series of labor market reforms. 
${ }^{2}$ See, e.g., Caliendo (2009) for a more detailed overview of the German income support systems and labor market policies, their recent reforms, and the effects of these reforms (where an assessment is already possible). A comprehensive survey and overview of the evaluation of the effectiveness of the German labor policy instruments is provided by Eichhorst and Zimmermann (2007).

${ }^{3}$ Although it is generally true that young people have suffered disproportionately during the Great Recession, Germany is one important exception as youth unemployment rates in 2009 were below their pre-recession value (Bell and Blanchflower, 2011).

${ }^{4}$ See Schäfer and Zimmermann (2009a) for a discussion of plans to place toxic assets in one or more "bad banks," and Schäfer and Zimmermann (2009b) for a comprehensive analysis of the financial market crisis.

${ }^{5}$ See Leifels et al. (2009) or IMF (2009) for a detailed overview of the budget items of the stimulus packages and the expenditures associated with these measures.

${ }^{6}$ Other requirements included, for example, that the car holder had to be a private person, that the old car had to be destroyed, and that the new car had to meet a specific emission standard.

7 See Brenke et al. (2011) for details about further amendments to laws and regulations.

${ }^{8}$ The employee's working hours are paid as usual. The fall in income due to lost working hours is partly compensated by the Federal Employment Agency. This amounts to 60 percent of the net earnings difference for workers without children and 67 percent for those with. Social security contributions continue as before, and paid leave (public holidays, vacation, as well as any other contractual agreements) also remain unaffected.

9 Additionally, employees worked on average 9.8 hours less paid overtime in 2009 than in 2008 (Zapf and Brehmer, 2010).

${ }^{10}$ The regulations governing the use of short-time work require that all other flexibility measures (e.g., working time accounts) have been already utilized. This requirement was slightly modified in early 2009 , but only in as far as working time accounts were not required to show a negative balance anymore (Zapf and Brehmer, 2010).

${ }^{11}$ Firms subject to financial frictions had a higher fraction of their employees in shorttime work and therefore relied on the subsidized alternative (Bohachova et al., 2011).

${ }^{12}$ However, it should be noted that the unemployment shock was relatively modest in Germany. Therefore, the actual role of unemployment benefits is presumably exaggerated in these simulations which assume the same shock for all countries.

${ }^{13}$ This argument is in line with the finding that firms using working time accounts have in general more persistent levels of employment, but there has been no additional effect of working time accounts on the extent of labor hoarding during the economic crisis (Bohachova et al., 2011).

${ }^{14}$ Other sectors currently facing shortages of skilled labor include health, IT and communications (Bosch et al., 2011). However, labor shortages will affect the German labor market more broadly in the long run. Assuming current trends, labor supply is expected to decrease by at least 3.5 million persons by 2025 (Fuchs et al., 2011).

${ }^{15}$ A more detailed assessment of the sectoral and regional composition of job and worker flows during the crisis is an interesting issue to consider in future research once reliable data sources become available. 
16 Note that the take-up rates of short-time work during the crisis were substantially lower in the Netherlands and Austria than in Germany (Cahuc and Carcillo, 2011).

\section{Competing interests}

The IZA Journal of Labor Policy is committed to the IZA Guiding Principles of Research Integrity. The authors declare that they have observed these principles.

\section{Acknowledgements}

We would like to thank Daniela Geppert for excellent research assistance. A first draft of this paper was circulated in 2010. We thank the anonymous referee, Juan F. Jimeno, David Neumark, Núria Rodríguez-Planas, Orley Ashenfelter, Alan Krueger and participants at the 2011 IZA/OECD Employment Seminar in Paris for helpful comments. All remaining errors are our own.

Responsible Editor: Juan Francisco Jimeno

Received: 28 January 2012 Accepted: 24 July 2012

Published: 9 October 2012

\section{References}

Algan Y, Dustmann C, Glitz A, Manning A (2010) The Economic Situation of First- and Second-Generation Immigrants in 613 France, Germany, and the United Kingdom. Econ J 120(542):4-30

Bargain O, Immervoll H, Peichl A, Siegloch S (2012) Distributional Consequences of Labor-Demand Shocks: the 20082009 Recession in Germany. Int Tax Publ Finance 19(1):118-138

Bell DNF, Blanchflower DG (2011) Young People and the Great Recession, IZA Discussion Paper 5674. Institute for the Study of Labor (IZA), Bonn

Blanchard OJ, Summers LH (1986) Hysteresis And The European Unemployment Problem. In: NBER Macroeconomics Annual 1986, Volume 1. National Bureau of Economic Research, Inc., Cambridge, MA, pp 15-90

Blum U, Freye S (2009) Die Abwrackprämie - wer zahlt die Zeche?, IWH Pressemitteilung 29/2009. Institut für Wirtschaftsforschung Halle (IWH), Halle

Boeri T, Brücker H (2011) Short-Time Work Benefits Revisited: Some Lessons from the Great Recession, IZA Discussion Paper 5635. Institute for the Study of Labor (IZA), Bonn

Bohachova O, Boockmann B, Buch CM (2011) Labor Demand During the Crisis: What Happened in Germany?, IZA Discussion Paper 6074. Institute for the Study of Labor (IZA), Bonn

Bosch H, Brücker H, Koppel O (2011) Fachkräftemangel: Scheinproblem oder Wachstumshemmnis? Wirtschaftsdienst 91 (9):583-593

Brenke K, Rinne U, Zimmermann KF (2011) Short-Time Work: The German Answer to the Great Recession, IZA Discussion Paper 5780. Institute for the Study of Labor (IZA), Bonn

Burda MC, Hunt J (2011) What Explains the German Labor Market Miracle in the Great Recession? Brookings PapEcon Act 42(1):273-335

Cahuc P, Carcillo S (2011) Is Short-Time Work a Good Method to Keep Unemployment Down?, IZA Discussion Paper 5430. Institute for the Study of Labor (IZA), Bonn

Caliendo M (2009) Income Support Systems, Labor Market Policies and Labor Supply: The German Experience, IZA Discussion Paper 4665. Institute for the Study of Labor (IZA), Bonn

Constant AF, Tien BN, Zimmermann KF, Meng J (2011) China's Latent Human Capital Investment: Achieving Milestones and Competing for the Top, IZA Discussion Paper 5650. Institute for the Study of Labor (IZA), Bonn (forthcoming in: Journal of Contemporary China, 2013)

Dolls M, Fuest C, Peichl A (2012) Automatic Stabilizers and Economic Crisis: US vs. Europe J Public Econ 96(3-4): 279-294

Eichhorst W, Grienberger-Zingerle M, Konle-Seidl R (2008) Activation Policies in Germany: From Status Protection to Basic Income Support. In: Eichhorst W, Kaufmann O, Konle-Seidl R (eds) Bringing the Jobless into Work? Springer, Berlin

Eichhorst W, Marx P (2011) Reforming German Labor Market Institutions: A Dual Path to Flexibility. Journal of European Social Policy 21(1):73-87

Eichhorst W, Zimmermann KF (2007) And Then There Were Four... How Many (and Which) Measures of Active Labor Market Policy Do We Still Need? Appl Econ Q 53(3):243-272

Fuchs J, Söhnlein D, Weber B (2011) Projektion des Arbeitskräfteangebots bis 2050: Rückgang und Alterung sind nicht mehr aufzuhalten. IAB Kurzbericht 16/2011. Institute for Employment Research (IAB), Nuremberg

Giersch H, Paqué K-H, Schmieding H (1992) The fading miracle: four decades of market economy in Germany. Cambridge University Press, Cambridge, UK, 651

Hachon C (2010) Do Beveridgian Pension Systems Increase Growth? J Popul Econ 23(2):825-831

IMF (2009) Germany: Staff Report for the 2008 Article IV Consultation, IMF Country Report 09/15, International Monetary Fund (IMF). Washington, D.C

Krueger AB, Pischke JS (1997) Observations and Conjectures on the U.S. Employment Miracle, NBER Working Paper 6146. National Bureau of Economic Research, Inc, Cambridge, MA

Lang FP (1990) Can the German 'Economic Miracle' be repeated? Intereconomics 25(5):248-252

Leifels A, Moog S, Raffelhüschen B (2009) Auswirkungen der Konjunkturpakete auf die öffentlichen Haushalte in 2009 und 2010. Kurzexpertise im Auftrag der Initiative Neue Soziale Marktwirtschaft, Freiburg

Möller J (2010) The German Labor Market Response in the World Recession: De-mystifying a Miracle. Journal for Labour Market Research 42(4):325-336 
OECD (2009) OECD Employment Outlook: Tackling the Jobs Crisis. Organization for Economic Cooperation and Development (OECD), Paris

Schäfer D, Zimmermann KF (2009a) Bad Bank(s) and Recapitalization of the Banking Sector. Intereconomics 44(4): $215-225$

Schäfer D, Zimmermann KF (2009b) Finanzmärkte nach dem Flächenbrand. Warum es dazu kam und was wir daraus lernen müssen, Wiesbaden

Schneider F (2003) Zunehmende Schattenwirtschaft in Deutschland: Eine wirtschafts- und staatspolitische Herausforderung. Vierteljahrshefte zur Wirtschaftsforschung 72(1):148-159

Schneider H (2008) Die Veränderung der Lohnersatzleistungen und die Reform der Vermittlungsprozesse im SGB III. Vierteljahrshefte zur Wirtschaftsforschung 77(1):20-37

Schneider H, Zimmermann KF (2010) Agenda 2020: Strategies to Achieve Full Employment in Germany, IZA Policy Paper 15. Institute for the Study of Labor (IZA), Bonn

Walterskirchen E (2001) Knappheit an Arbeitskräften, WIFO Monatsberichte 6, 391-395. Austrian Institute of Economic Research (WIFO), Vienna

Zapf I, Brehmer W (2010) Flexibilität in der Wirtschaftskrise: Arbeitszeitkonten haben sich bewährt, IAB Kurzbericht 22 2010. Institute for Employment Research (IAB), Nuremberg

doi:10.1186/2193-9004-1-3

Cite this article as: Rinne and Zimmermann: Another economic miracle? The German labor market and the Great Recession. IZA Journal of Labor Policy 2012 1:3.

\section{Submit your manuscript to a SpringerOpen ${ }^{\circ}$ journal and benefit from:}

- Convenient online submission

- Rigorous peer review

- Immediate publication on acceptance

- Open access: articles freely available online

- High visibility within the field

Retaining the copyright to your article

Submit your next manuscript at $\gg$ springeropen.com 